\title{
Juvenile Atlantic cod behavior appears robust to near-future $\mathrm{CO}_{2}$ levels
}

Fredrik Jutfelt ${ }^{1,2^{*}}$ and Maria Hedgärde ${ }^{1}$

\begin{abstract}
Background: Ocean acidification caused by the anthropogenic release of $\mathrm{CO}_{2}$ is considered a major threat to marine ecosystems. One unexpected impact of elevated water $\mathrm{CO}_{2}$ levels is that behavioral alterations may occur in tropical reef fish and certain temperate fish species. These effects appear to alter many different types of sensory and cognitive functions; if widespread and persistent, they have the potential to cause ecosystem changes.

Methods: We investigated whether economically and ecologically important Atlantic cod also display behavioral abnormalities by exposing 52 juvenile cod to control conditions (500 $\mu \mathrm{atm}$, duplicate tanks) or an end-of-thecentury ocean acidification scenario (1000 $\mu \mathrm{atm}$, duplicate tanks) for one month, during which time the fish were examined for a range of behaviors that have been reported to be affected by elevated $\mathrm{CO}_{2}$ in other fish. The behaviors were swimming activity, as measured by number of lines crossed per minute, the emergence from shelter, determined by how long it took the fish to exit a shelter after a disturbance, relative lateralization (a measure of behavioral turning side preference), and absolute lateralization (the strength of behavioral symmetry).

Results: We found no effect of $\mathrm{CO}_{2}$ treatment on any of the four behaviors tested: activity $(\mathrm{F}=1.61, \mathrm{p}=0.33)$, emergence from shelter $(F=0.13, p=0.76)$, relative lateralization $(F=2.82, p=0.50)$, and absolute lateralization $(\mathrm{F}=0.80, \mathrm{p}=0.26)$.
\end{abstract}

Conclusion: Our results indicate that the behavior of Atlantic cod could be resilient to the impacts of near-future levels of water $\mathrm{CO}_{2}$.

Keywords: Carbon dioxide, Teleost, Climate change, Boldness, Teleost, Lateralization, Behavior, Gadus morhua, Ocean acidification

\section{Introduction}

The accelerating rate of anthropogenic emissions of $\mathrm{CO}_{2}$ [1] results in higher oceanic surface $\mathrm{pCO}_{2}$ and lower $\mathrm{pH}$ in a process known as ocean acidification. For the 650,000 years preceding the Industrial Revolution, the $\mathrm{CO}_{2}$ concentration in the atmosphere did not exceed $300 \mathrm{ppm}$ [2]; however, the atmospheric levels are now at $400 \mathrm{ppm}$ and may reach close to $1000 \mathrm{ppm}$ by the end of the current century according to the fossil fuel intensive IPCC RCP8.5 emission scenario [1]. Numerous studies have investigated the effect of ocean acidification-like $\mathrm{CO}_{2}$ exposure on invertebrates [3], and the responses differ dramatically between groups, species,

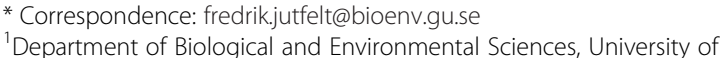

* Correspondence: fredrik.jutfelt@bioenv.gu.se
${ }^{1}$ Department of Biological and Environmental Sciences, University of Gothenburg, PO Box 463SE-405 30 Göteborg, Sweden

${ }^{2}$ The Lovén Centre Kristineberg, Kristineberg 566, SE-451 78 Fiskebäckskil, Sweden
}

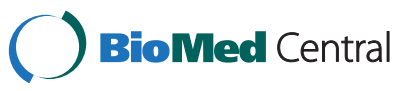

(C) 2015 Jutfelt and Hedgärde; licensee BioMed Central. This is an Open Access article distributed under the terms of the Creative Commons Attribution License (http://creativecommons.org/licenses/by/4.0), which permits unrestricted use, distribution, and reproduction in any medium, provided the original work is properly credited. The Creative Commons Public Domain Dedication waiver (http://creativecommons.org/publicdomain/zero/1.0/) applies to the data made available in this article, unless otherwise stated. environments and life stages [4]. In contrast, fewer studies have investigated the possible effects of ocean acidification on fish because they have long been considered among the most $\mathrm{CO}_{2}$-tolerant marine organisms [5-7].

However, a number of reports in recent years have suggested that the behavior of coral reef fish, including their activity level, boldness, behavioral asymmetry (lateralization), and responses to olfactory and auditory cues, may be affected by ocean acidification (see the review by [8]). These behavioral effects appeared at ocean acidification-relevant levels of $\mathrm{CO}_{2}$ (700-1200 $\left.\mu \mathrm{atm}\right)$. Behaviors such as foraging, competition and predator avoidance are important in many aspects of the lives of fish, and any disruption of normal behavior is expected to affect fitness [8]. A switch from repulsion to attraction to the scent of predators has been reported in several coral reef fish species after $\mathrm{CO}_{2}$ exposure $[8,9]$.

aricle, unless otherwise stated. 
Juvenile leopard coral grouper (Plectropomus leopardus) exposed to $965 \mu \mathrm{atm} \mathrm{CO}_{2}$ was reported to dramatically increase spontaneous activity and decrease shelter usage, a pattern of behaviors that is indicative of hyperactivity and/ or increased boldness [10]. In addition, several species of damsel fish and cardinal fish living near natural volcanic $\mathrm{CO}_{2}$ seeps were reported to show the same behavioral effects on olfaction, activity and boldness, which may indicate that the effect is not restricted to laboratory $\mathrm{CO}_{2}$ exposure [11].

Lateralization is the asymmetry of brain function manifested as asymmetrical behavior, and behavioral lateralization has recently been shown to be significantly reduced by $\mathrm{CO}_{2}$ exposure in the coral fish Neopomacentrus azysron [12] as well as in the temperate three-spined stickleback (Gasterosteus aculeatus) [13,14]. Relative behavioral lateralization is the left- or right-side preference of an individual or a population in a choice situation, and absolute behavioral lateralization is the strength of that side bias. Various fitness advantages have been correlated with lateralized (showing a side preference) behavior [15,16], and stronger lateralization correlates with increased escape reactivity. This observation suggests that lateralization may confer a fitness advantage through an increased ability to escape from predator attacks [15], but causality has yet to be demonstrated.

Recently, it was suggested that the reversal of lateralization and olfaction is related to a reversal of $\mathrm{GABA}_{\mathrm{A}}$ receptor function [14,17]. Most inhibitory synapses in the brain of vertebrates involve the neurotransmitter GABA [18], and it has been suggested that a decrease in plasma $\mathrm{Cl}^{-}$and an increase in $\mathrm{HCO}_{3}^{-}$can disrupt the hyperpolarization function of the $\mathrm{GABA}_{\mathrm{A}}$ receptor, which may become dysfunctional or excitatory. This reversal of $\mathrm{GABA}_{\mathrm{A}}$ function could explain the shifts and, in some cases, reversals in behavior [14,17].

Although it has been reported that a number of Australian coral reef fishes demonstrate altered behavior when exposed to $\mathrm{CO}_{2}$, there is fragmented knowledge regarding $\mathrm{CO}_{2}$-induced behavioral shifts in species from other parts of the world. Adult three-spined sticklebacks were reported to display altered behavior following longterm exposure to $990 \mu \mathrm{atm} \mathrm{CO}_{2}$ [13], and the phototactic response in newly hatched larvae of temperate twospotted goby (Gobiusculus flavescens) was increased by $\mathrm{CO}_{2}$ exposure [19]. Furthermore, temperate Pacific splitnose rockfish (Sebastes diploproa) increased their time spent in darkness when exposed to elevated $\mathrm{CO}_{2}$ levels [20], indicating reduced boldness in contrast to the increased boldness reported in coral reef fish. Other temperate fishes have been suggested to be less affected by elevated $\mathrm{pCO}_{2}[21,22]$.

Atlantic cod (Gadus morhua) is an ecologically and economically important species that has a history of being exposed to overfishing [23] and cod populations may therefore be sensitive to the effects of additional stressors such as ocean acidification. It has been suggested that large juvenile cod are physiologically tolerant to very high $\mathrm{CO}_{2}$ levels, maintaining swimming capacity and aerobic scope despite long exposure. Increased gill $\mathrm{Na}^{+} / \mathrm{K}^{+}$-ATPase activity has been suggested as an acclimation mechanism to improve the capacity for gill ion transport [6]. In contrast to their high physiological acclimation capacity, Frommel et al. [24] demonstrated that Atlantic cod larvae could suffer severe and, most likely, lethal tissue necrosis when exposed to 1800 and $4200 \mu \mathrm{atm} \mathrm{CO}_{2}$. Larvae from the same experiment were also investigated for behavioral changes using a 3-D tracking system, but major deviations from normal behavior were not observed despite the very high $\mathrm{pCO}_{2}$ [25]. Post-settlement juveniles, however, exhibit a different behavioral gamut than pelagic larvae, including benthic exploration and interaction with the substrate, as well as shelter use [26-28]. This makes the juvenile stage suitable for testing behaviors in specific arenas, such as lateralization double T-chambers, activity tanks and emergence from shelter tanks.

Therefore, the aim of the present study was to investigate whether juvenile Atlantic cod show alterations in these specific behaviors when exposed to elevated $\mathrm{CO}_{2}$ levels. Based on the behaviors affected by exposure to elevated $\mathrm{CO}_{2}$ levels in coral reef fish and sticklebacks, three different behavior experiments were performed in control and high $\mathrm{CO}_{2}$-exposed cod: activity trials, emergence from shelter and lateralization.

\section{Materials and methods}

\section{Fish rearing and treatment}

The ethical committee for animal experimentation approved all experiments (Gothenburg, Sweden, ethical permits Jutfelt 100-2010 and Jutfelt 151-2011).

The fish (56 juvenile Atlantic cod) were captured by Kristineberg Marine station (lat. 58.249717, long. 11.445522), Lysekil, Sweden, with hand nets, seine nets and fish trap cages. Length and weight was measured for each individual at the start of the experiment. Fish were randomly distributed to four tanks, two for each treatment. All experiments were conducted in thermally constant rooms that ensured temperature stability at all times. The light regime was L16:D8 $h$.

Four dark cylindrical fiberglass $100 \mathrm{~L}$ aquaculture tanks with coned bottoms (Strandvik Plast AS, Strandvik, Norway) were continuously supplied with flow-through deep water that was continuously pumped from 30 meters depth in the fjord. Each fish tank was supplied with flowthrough water at $3 \mathrm{~L}$ per minute from its own $200 \mathrm{~L}$ header tank, which were heavily aerated and in two of the header tanks the $\mathrm{CO}_{2}$ levels were manipulated. The fish 
were thus exposed to control water $(532 \mu \mathrm{atm} \pm 43 \mathrm{SD})$ or water with elevated $\mathrm{CO}_{2}$ levels $(1014 \mu$ atm $\pm 76 \mathrm{SD})$ for the duration of the 30 day exposure period. The exposure duration was chosen to presumably allow acclimation, as acclimation to other environmental stressors such as temperature occurs over days to weeks [29]. The fish tanks were covered with clear plastic lids to reduce gas exchange. The $\mathrm{pCO}_{2}$ of the fish tanks was measured at least once daily using an infrared $\mathrm{pCO}_{2}$ measurement system, a Vaisala GM70 (Vaisala, Helsinki, Finland) connected to a gas-permeable silicone membrane according to [30-32]. $\mathrm{pH}$-stat computers (Aquamedic, Bissendorf, Germany) controlled the $\mathrm{pH}$ of the two $\mathrm{CO}_{2}$-manipulated header tanks by bubbling of pure $\mathrm{CO}_{2}$ (Aga gas, Gothenburg, Sweden) through solenoid valves. The temporal $\mathrm{pH}$ variance of the header tanks was low $(<0.1 \mathrm{pH}$ units), and the $\mathrm{pH}$ variability of the fish tanks was negligible $(<0.05$ $\mathrm{pH}$ units). Temperature and salinity were recorded continuously, with a mean temperature of $14.4^{\circ} \mathrm{C} \pm 0.44$ (SD) and a mean salinity of $33.1 \pm 0.8$ (SD) PSU. The alkalinity of this deep water supply was very stable and titrated weekly. Oxygen saturation in the fish tanks was always above $90 \%$. The carbonate chemistry was calculated in CO2calc (Hansen, USGS, USA) using data for $\mathrm{pCO}_{2}$, salinity, temperature, and alkalinity. The results are shown in Table 1.

The cod were fed shrimp daily, and any mortality was counted. The fish were not individually tagged because they were to be released after the experiment. The starting lengths and weights, as well as the mortality in the tanks, are presented in Table 2. As mortality occurred in all tanks, it was not possible to determine the growth rates. Half of the mortality was due to cannibalism; a few fish escaped, and the rest died of unknown causes without obvious pathology. After the behavioral tests, the fish were kept for chemosensory evaluation in a related experiment, the results of which have been published in Jutfelt and Hedgärde [31]; thereafter, the fish were released back into the fjord at the site of capture.

Table 1 Water chemistry for the treatments Control and Elevated $\mathrm{CO}_{2}$

\begin{tabular}{|c|c|c|}
\hline Parameter & Control & Elevated $\mathrm{CO}_{2}$ \\
\hline 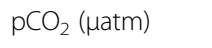 & $532.4 \pm 42.7$ & $1013.5 \pm 76.0$ \\
\hline Alkalinity (TA) & $2350 \pm 37.1$ & $2363 \pm 53.7$ \\
\hline Salinity (PSU) & $33.1 \pm 0.8$ & $33.1 \pm 0.8$ \\
\hline Temp $\left({ }^{\circ} \mathrm{C}\right)$ & $14.4 \pm 0.5$ & $14.4 \pm 0.5$ \\
\hline $\mathrm{pH}_{\text {tot }}($ calc. $)$ & $7.95 \pm 0.04$ & $7.69 \pm 0.03$ \\
\hline Saragonite (calc.) & $2.10 \pm 0.21$ & $1.22 \pm 0.08$ \\
\hline $\Omega$ calcite (calc.) & $3.29 \pm 0.33$ & $1.90 \pm 0.13$ \\
\hline
\end{tabular}

Temperature, salinity, $\mathrm{pCO}_{2}$ and alkalinity $\left(\mathrm{A}_{\mathrm{T}}\right)$ are measured data; $\mathrm{pH}_{\text {tot }}$, $\Omega_{\text {aragonite }}$ and $\Omega_{\text {calcite }}$ were calculated data using CO2calc (USGS, USA). The data are presented as the means \pm SD.
From exposure day 12 and onwards, the fish were used in behavioral tests. The test fish were randomly sampled from the tanks, and most of the fish were used in all trials. All tests were performed during the daytime, at the treatment water $\mathrm{pCO}_{2}$, temperature and light conditions to which the fish were acclimated. The water in the test chambers was taken from the respective treatment tanks and replaced between trials to maintain water quality and $\mathrm{pCO}_{2}$. The $\mathrm{pH}$ of the trial water did not differ from $\mathrm{pH}$ in the treatment tanks. All trial tanks were visually shielded from disturbance.

\section{Activity trials}

The activity trials were performed during day 12 to 19 after exposure initiation. The activity arena was a 50x50 $\mathrm{cm}$ Plexiglas tank with a painted grid bottom forming nine equal squares, and the water depth was $15 \mathrm{~cm}$. The tank was visually shielded from disturbance. A video camera positioned above the tank was used to record the experiments. Single fish were placed in the tank and filmed for one hour, of which the first 30 minutes were considered the acclimatization time. During the remaining 30 minutes, the activity was measured as the number of lines crossed, similar to the activity experiment performed by Munday et al. [10]. The data are presented as lines crossed per minute.

\section{Emergence from shelter}

The experiment on emergence from shelter was performed after 26 days of exposure. The emergence-fromshelter test is commonly used to estimate fish boldness [33]. The arena used for the emergence-from-shelter experiment was a $50 \times 50 \mathrm{~cm}$ plastic tank with a rock and plastic algae shelter $(10 \times 10 \mathrm{~cm})$ in one corner, and the water depth was $15 \mathrm{~cm}$. A video camera positioned above the tank was used to record the experiments. Each fish was left to acclimatize to the experimental tank for $5 \mathrm{mi}-$ nutes before it was chased by hand into the shelter. The chasing was short and similar for all fish, and the fish quickly entered the shelter. The time to emerge from the shelter was then measured using the video footage, similar to the methods described in Munday et al. [10].

\section{Lateralization}

Lateralization was tested on days 29 and 30. A double T-maze runway was used for the lateralization trials using the methods described previously $[12,13]$. The fish were given 5 minutes to acclimatize to the T-maze before starting the trial. The fish were gently encouraged down the central channel using a plastic rod (approaching but not touching the fish) and forced to make a turning decision at each T-crossing. The fish swam spontaneously and did not require much encouragement to follow the central channel and make turning decisions. The procedure was 
Table 2 Tank means of the initial lengths and weights of the fish

\begin{tabular}{lllll}
\hline & Control tank A & Control tank $\mathbf{B}$ & $\mathbf{C O}_{2} \operatorname{tank} \mathbf{C}$ & $\mathbf{C O}_{\mathbf{2}} \operatorname{tank} \mathbf{D}$ \\
\hline Length $(\mathrm{cm})$ & $8.73 \pm 0.18$ & $9.20 \pm 0.46$ & $9.44 \pm 0.31$ & $10.72 \pm 0.54$ \\
Weight $(\mathrm{g})$ & $5.76 \pm 0.34$ & $7.52 \pm 1.48$ & $8.37 \pm 0.95$ & $13.02 \pm 2.38$ \\
Mortality (\%) & 17 & 11 & 15 & 33 \\
\hline
\end{tabular}

The mortality is the total tank mortality over the 30-day exposure in percentage of the starting number of fish in the tank.

then repeated in the reverse direction. In total, 14 decisions per fish were recorded. The relative and absolute lateralization indices were calculated using:

$$
\begin{aligned}
L_{r}= & {[(\text { Turns to the right }- \text { Turns to the left }) /} \\
& (\text { Turns to the right }+ \text { Turns to the left })] \cdot 100
\end{aligned}
$$

and

$$
L_{a}=\left|L_{r}\right|
$$

according to [34].

\section{Data analysis}

Statistical analyses were performed in SPSS with a significance level of 0.05 . Because all data were normally distributed (Kolmogorov-Smirnov $\mathrm{p}>0.05$ ), parametric tests were used. A nested ANOVA (tank nested under treatment) was performed for activity, shelter, relative lateralization and absolute lateralization. When tank effects were found, a post hoc test was used to determine which tanks were significantly different. The data are presented as the mean \pm SEM, unless otherwise noted.

\section{Results}

In the activity trial, a significant tank effect was observed, with fish from one $\mathrm{CO}_{2}$-treated tank exhibiting higher activity than the fish from the other three tanks $(p=0.012)$. The cause of this increased activity is unknown but could be caused by random size differences, as the higher-activity tank contained two of the largest individuals. However, despite the higher activity in one $\mathrm{CO}_{2}$ tank, there was no significant effect of the treatment (Figure 1) (nested ANOVA; $\mathrm{F}=1.61, \mathrm{p}=0.332, \mathrm{n}_{\text {control }}=$ $\left.22, \mathrm{n}_{\mathrm{CO} 2}=23\right)$.

There was no significant difference in the time to emerge from shelter between the two groups (nested ANOVA; $\mathrm{F}=0.13, \mathrm{p}=0.755, \mathrm{n}_{\text {control }}=22$, and $\mathrm{n}_{\mathrm{CO} 2}=20$ (Figure 2), and no tank effect.

There was a tendency for the $\mathrm{CO}_{2}$ fish to be rightbiased and the control fish to be left-biased, but there was no significant difference in relative lateralization $\left(\mathrm{L}_{\mathrm{r}}\right)$ (nested ANOVA; $\mathrm{F}=2.82, \mathrm{p}=0.502, \mathrm{n}_{\text {control }}=21, \mathrm{n}_{\mathrm{CO} 2}=$ 17) (Figure 3A). However, there was a significant effect between tanks $(\mathrm{p}=0.012)$. There was no significant difference in the absolute lateralization $\left(\mathrm{L}_{\mathrm{a}}\right)$ (nested ANOVA; $\mathrm{F}=0.80, \mathrm{p}=0.255, \mathrm{n}_{\text {control }}=21, \mathrm{n}_{\mathrm{CO} 2}=17$ ) (Figure 3B).

\section{Discussion}

Juvenile Atlantic cod and three-spined stickleback have overlapping habitats and temperature ranges, and both species are relatively euryhaline [35]. The recent finding that sticklebacks, similar to a large number of tropical coral reef species, can demonstrate alterations in behavior following the long-term exposure to elevated $\mathrm{pCO}_{2}$ could indicate that most teleosts would show these effects. The behaviors tested in this study were chosen as

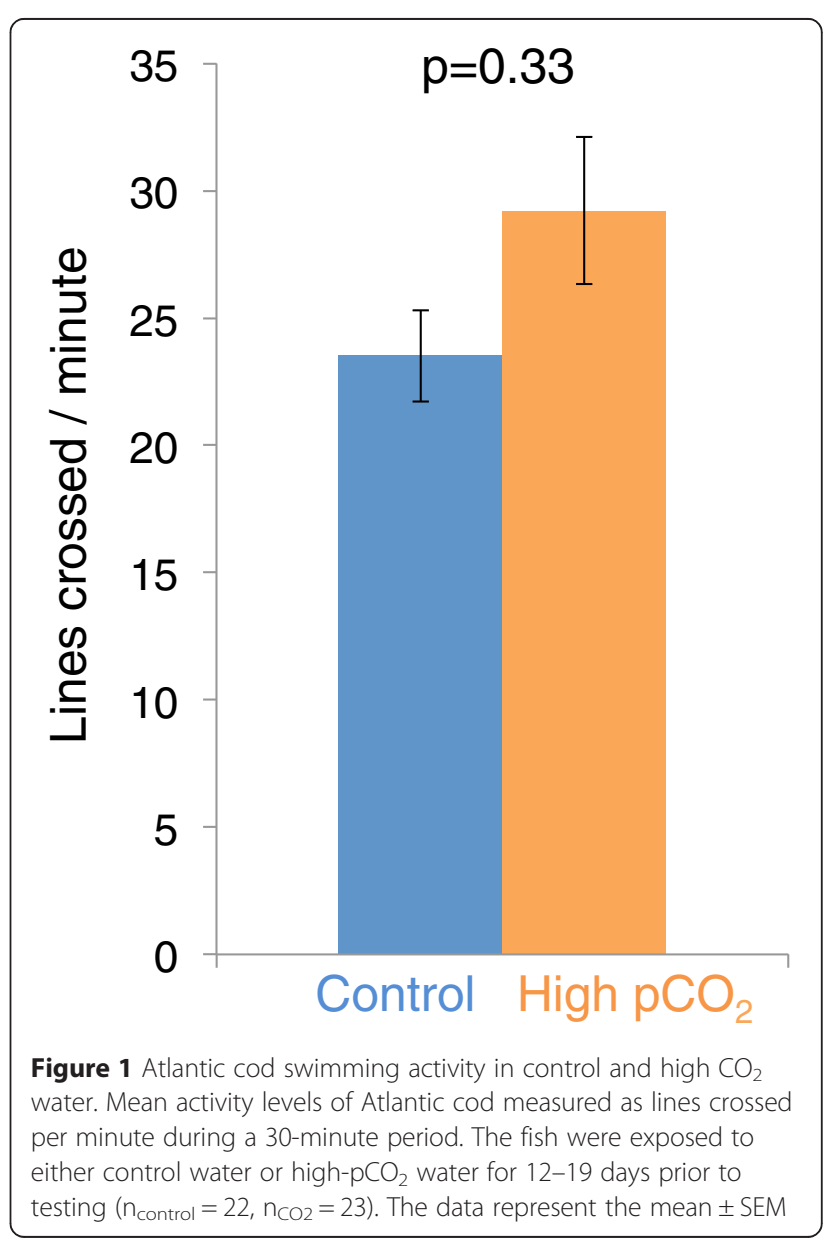




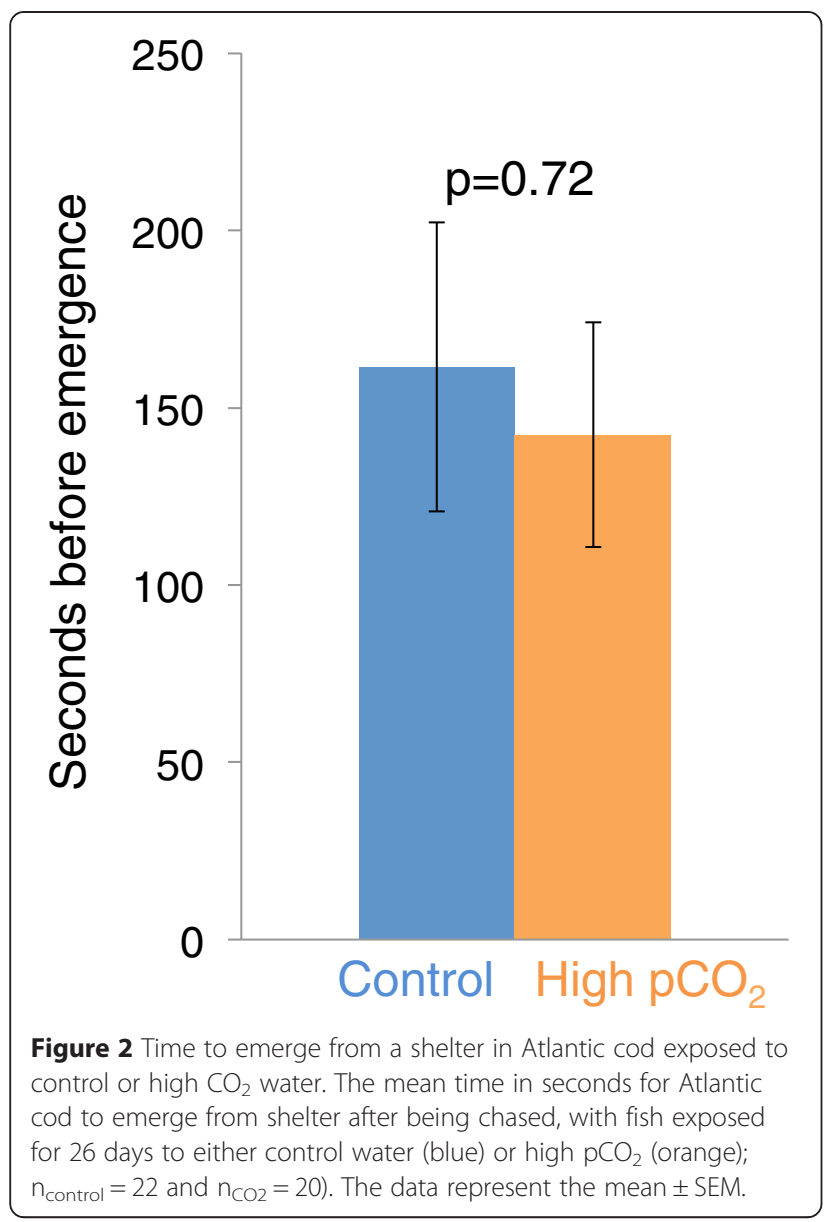

they were previously reported to be affected by $\mathrm{CO}_{2}$ exposure in tropical reef fish. In the previous studies, the activity was increased [10], the time until emergence from shelter was reduced [10], and lateralization was reduced $[12,17]$. In sticklebacks, both lateralization and boldness were found to be affected [13].

However, in the present study on Atlantic cod, none of the behaviors measured were significantly affected by $\mathrm{CO}_{2}$ treatment. Although our results differed from those found for juveniles of other investigated species, they were consistent with the data from larval Atlantic cod, in which the larvae were found to be behaviorally tolerant to very high $\mathrm{CO}_{2}$ levels [25]. As shown by a related experiment, the dramatic reversal of olfactory preference shown for many Australian coral reef fish was not present in juvenile Atlantic cod [31]. Instead, the juvenile Atlantic cod avoided predator odor to the same high degree ( $65 \%$ of the time in control water), regardless of their exposure water $\mathrm{pCO}_{2}$. The lack of behavioral shift in Atlantic cod was somewhat surprising, as many other species have been reported to show abnormal behavior. Atlantic cod are known to forage in hypercapnic deep water [36] and may therefore be physiologically adapted to be tolerant to high environmental $\mathrm{CO}_{2}$ levels. These results together suggest that behavioral effects of $\mathrm{CO}_{2}$ are not universal in teleosts and that the full geographical and phylogenetic extent of behavioral effects of $\mathrm{CO}_{2}$ exposure needs to be elucidated. There are also indications that even within species that appear sensitive to $\mathrm{CO}_{2}$-induced behavioral abnormalities, some behaviors are more robust than others. Lateralization in three-spined sticklebacks appear sensitive [13,37], whereas avoidance of bird strikes may be less sensitive or completely resistant [37]. Such
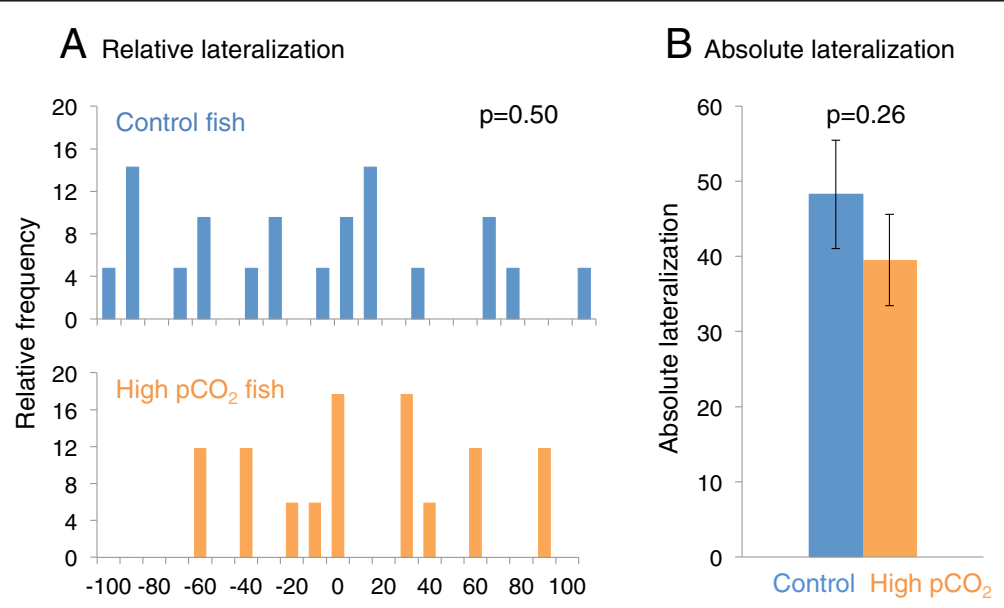

Figure 3 Relative and absolute lateralization in Atlantic cod exposed to control or high $\mathrm{CO}_{2}$ water. A. Relative lateralization (frequency in \%) of

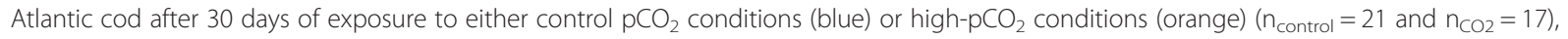
where -100 represents $100 \%$ left turns and 100 represents 100\% right turns. The vertical axis shows the frequency (\%). $\mathbf{B}$. Mean absolute lateralization; $n_{\text {control }}=21$ and $n_{\mathrm{CO} 2}=17$ ). The data represent the mean \pm SEM. 
differences in sensitivity within species make extrapolations from highly artificial laboratory experiments to impacts on wild populations difficult.

Hyperactivity has been suggested to be an effect of high $\mathrm{CO}_{2}$ exposure in fish. The most extreme example reported was in leopard coral grouper, with a $9000 \%$ increase in swimming activity, as measured by number of lines crossed [10]. In the present experiment, the high $\mathrm{CO}_{2}$ group did not behave significantly differently from the control group. As retrospective power analysis is not recommended [38], we cannot be sure how large effect sizes we could potentially have missed using the current experimental design. However, it is clear that effect sizes of the magnitude reported in many studies on coral reef fish would have been detected by the current experiments.

Some previous experiments have interpreted detected behavioural disturbances as altered function of the central nervous system (CNS) [39], with altered function of inhibitory $\mathrm{GABA}_{\mathrm{A}}$ receptors implicated as a likely mechanism [17]. However, the finding that fish can acutely detect the water $\mathrm{CO}_{2}$ levels and respond to it, even after long term exposure, should not be ignored when designing experiments [31]. It is possible that sensory detection of elevated $\mathrm{CO}_{2}$ levels during behavioural trials could alter the behaviour of the fish, for example triggering a search response for better water quality [32]. It can therefore be advisable to include in experimental designs acute $\mathrm{CO}_{2}$ exposures, to investigate if such exposures triggers behavioural alterations.

Although we did not find major behavioral disturbances in Atlantic cod, in accordance with other studies $[25,31]$, we cannot rule out effects of elevated $\mathrm{CO}_{2}$ of smaller effect sizes, or effects on specific behaviors. However, the behaviors that are highly affected in many coral reef fish appear insensitive to $\mathrm{CO}_{2}$ in Atlantic cod (current results and Jutfelt and Hedgärde [31]). Even if the behaviors are robust to elevated $\mathrm{pCO}_{2}$, there are nonetheless results showing that future ocean acidification may affect Atlantic cod, including the organ damage shown in Atlantic cod larvae [24]. There is also the potential of ecosystem effects from ocean acidification that could impact Atlantic cod through indirect mechanisms such as interspecific competition [40] or trophic interactions and food quality $[41,42]$.

\section{Conclusions}

The majority of experiments to date on ocean acidification and fish behavior show dramatic effects of elevated $\mathrm{CO}_{2}$ levels. This suggests either that most of the fish tested demonstrate abnormal behaviors following high $\mathrm{pCO}_{2}$ exposure or that negative results are published to a lower degree, possibly because of researcher or publication biases [43]. Regardless, the results obtained in this study complicate the prediction of future effects of ocean acidification on fish, suggesting that behavioral effects could be negligible in some species and that we might not be able to make good predictions until more species from representative geographical and phylogenetic groups are tested and published.

\section{Competing interests}

The authors declare that they have no competing interests.

\section{Authors' contributions}

Both authors designed the study and performed the experiment. $\mathrm{MH}$ performed all behavioral measurements; both authors analyzed the data. FJ wrote the manuscript. Both authors read and approved the final manuscript.

\section{Acknowledgments}

We would like to thank Kim Hellgren, Leon Green, Bengt Lundve, Marian $\mathrm{Hu}$ and Niklas Andersson for the excellent animal handling and technical assistance. This research was funded by the Swedish Research Council Formas, through grant Jutfelt 2009-596.

Received: 16 March 2015 Accepted: 29 April 2015

Published online: 23 May 2015

\section{References}

1. IPCC. Climate Change 2013: the Physical Science Basis. Contribution of Working Group I to the Fifth Assessment Report of the Intergovern- Mental Panel on Climate Change. Cambridge, U.K: Cambridge University Press; 2013. p. 1-1552.

2. Siegenthaler U, Stocker TF, Monnin E, Lüthi D, Schwander J, Stauffer B, et al. Stable carbon cycle-climate relationship during the late Pleistocene. Science. 2005;310:1313-7

3. Doney SC, Ruckelshaus M, Emmett Duffy J, Barry JP, Chan F, English CA, et al. Climate change impacts on marine ecosystems. Annu Rev Marine Sci. 2012;4:11-37.

4. Kroeker KJ, Kordas RL, Crim RN, Singh GG. Meta-analysis reveals negative yet variable effects of ocean acidification on marine organisms. Ecol Lett. 2010;13:1419-34.

5. Melzner F, Gutowska MA, Langenbuch M, Dupont S, Lucassen M, Thorndyke $\mathrm{MC}$, et al. Physiological basis for high $\mathrm{CO} 2$ tolerance in marine ectothermic animals: pre-adaptation through lifestyle and ontogeny? Biogeosciences. 2009;6:2313-31.

6. Melzner F, Göbel S, Langenbuch M, Gutowska MA, Pörtner HO, Lucassen M. Swimming performance in Atlantic Cod (gadus morhua) following long-term (4-12 months) acclimation to elevated seawater P(CO2). Aquat Toxicol. 2009;92:30-7.

7. Gräns A, Jutfelt F, Sandblom E, Jönsson E, Wiklander K, Seth H, et al. Aerobic scope fails to explain the detrimental effects on growth resulting from warming and elevated $\mathrm{CO}_{2}$ in Atlantic halibut. J Exp Biol. 2014;217:711-7.

8. Briffa M, la Haye de K, Munday PL. High CO2 and marine animal behaviour: potential mechanisms and ecological consequences. Marine Pollution Bulletin. 2012;64:1519-28.

9. Munday PL, Dixson DL, McCormick Ml, Meekan M, Ferrari MCO, Chivers DP. Replenishment of fish populations is threatened by ocean acidification. Proc Natl Acad Sci USA. 2010;107:12930-4.

10. Munday PL, Pratchett MS, Dixson DL, Donelson JM, Endo GGK, Reynolds AD, et al. Elevated $\mathrm{CO} 2$ affects the behavior of an ecologically and economically important coral reef fish. Mar Biol. 2013;160:2137-44.

11. Munday PL, Cheal AJ, Dixson DL, Rummer JL, Fabricius KE. Behavioural impairment in reef fishes caused by ocean acidification at $\mathrm{CO} 2$ seeps. Nature Climate Change. 2014;4(6):487-92. http://doi.org/10.1038/ nclimate2195.

12. Domenici P, Allan B, McCormick Ml, Munday PL. Elevated carbon dioxide affects behavioural lateralization in a coral reef fish. Biol Lett. 2012;8:78-81.

13. Jutfelt F, Bresolin de Souza K, Vuylsteke A, Sturve J. Behavioural disturbances in a temperate fish exposed to sustained high-CO2 levels. PLoS ONE. 2013:8:e65825.

14. Lai F, Jutfelt F, Nilsson GE. Itered neurotransmitter function in CO2-exposed stickleback (Gasterosteus aculeatus): a temperate model species for ocean acidification research. Conservation Physiology. 2015;3:cov018-cov018. 
15. Dadda M, Koolhaas WH, Domenici P. Behavioural asymmetry affects escape performance in a teleost fish. Biol Lett. 2010;6:414-7.

16. Dadda M. Lateralized female topminnows can forage and attend to a harassing male simultaneously. Behavioral Ecology. 2006:17:358-63.

17. Nilsson GE, Dixson DL, Domenici P, McCormick MI, Sørensen C, Watson S-A, et al. Near-future carbon dioxide levels alter fish behaviour by interfering with neurotransmitter function. Nature Climate Change. 2012;2:201-4.

18. Rabow LE, Russek SJ, Farb DH. From ion currents to genomic analysis: Recent advances in GABAA receptor research. Synapse. 2004;21:189-274.

19. Forsgren $\mathrm{E}$, Dupont $\mathrm{S}$, Jutfelt $\mathrm{F}$, Amundsen $\mathrm{T}$. Elevated $\mathrm{CO} 2$ affects embryonic development and larval phototaxis in a temperate marine fish. Ecol Evol. 2013;3:3637-46.

20. Hamilton TJ, Holcombe A, Tresguerres M. CO2-induced ocean acidification increases anxiety in Rockfish via alteration of GABAA receptor functioning. Proc Biol Sci. 2013;281:20132509-20132509.

21. Sundin J, Rosenqvist G, Berglund A. Altered oceanic pH impairs mating propensity in a pipefish. Ethology. 2012;119:86-93.

22. Sundin J, Jutfelt F. 9-28 days of exposure to elevated $\mathrm{pCO}_{2}$ reduces avoidance of predator odour but had no effect on behavioural lateralization or swimming activity in a temperate wrasse (Ctenolabrus rupestris). ICES J Marine Sci 2015. (In press).

23. Rose GA. Reconciling overfishing and climate change with stock dynamics of Atlantic cod ( gadus morhua) over 500 years. Can J Fish Aquat Sci. 2004;61:1553-7.

24. Frommel AY, Maneja R, Lowe D, Malzahn AM, Geffen AJ, Folkvord A, et al. Severe tissue damage in Atlantic cod larvae under increasing ocean acidification. Nature Climate Change. 2011;2:42-6.

25. Maneja RH, Frommel AY, Browman HI, Clemmesen C, Geffen AJ, Folkvord A, et al. The swimming kinematics of larval Atlantic cod, gadus morhua L., are resilient to elevated seawater pCO2. Mar Biol. 2012;160:1963-72.

26. Vollset KW, Folkvord A, Browman HI. Foraging behaviour of larval cod (Gadus morhua) at low light intensities. Mar Biol. 2011;158:1125-33.

27. Gotceitas V, Brown JA. Substrate selection by juvenile Atlantic cod (Gadus morhua): effects of predation risk. Oecologia. 1993;93:31-7.

28. Grant SM, Brown JA. Diel foraging cycles and interactions among juvenile Atlantic cod (Gadus morhua) at a nearshore site in Newfoundland. Canadian Journal of Fisheries and Aquatic Sciences, 1998;(55):1307-16. http://doi.org/10.1139/f97-291.

29. Beitinger TL, Lutterschmidt WI. Measures of thermal tolerance. In Encyclopedia of Fish Physiology: From Genome to Environment. Edited by Farrell AP. San Diego, CA, USA: Elsevier Inc; 2011.

30. Hari P, Pumpanen J, Huotari J, Kolari P, Grace J, Vesala T, et al. High-frequency measurements of productivity of planktonic algae using rugged nondispersive infrared carbon dioxide probes. Limnol Oceanogr: Methods. 2008;6:347-54.

31. Jutfelt F, Hedgärde M. Atlantic cod actively avoid CO2 and predator odour, even after long-term CO2 exposure. Front Zool. 2013;10:81.

32. Green $L$, Jutfelt $F$. Elevated carbon dioxide alters the plasma composition and behaviour of a shark. Biol Lett. 2014;10:20140538.

33. Brown C, Braithwaite VA. Size matters: a test of boldness in eight populations of the poeciliid brachyraphis episcopi. Animal Behaviour. 2004:68:1325-9.

34. Bisazza A, Facchin L, Pignatti R, Vallortigara G. Lateralization of detour behaviour in poeciliid fish: the effect of species, gender and sexual motivation. Behav Brain Res. 1998:91:157-64.

35. Froese R, Pauly D. Fishbase. 2015 (World Wide Web electronic publication)

36. Neuenfeldt S, Andersen KH, Hinrichsen HH. Some Atlantic cod gadus morhuain the Baltic Sea visit hypoxic water briefly but often. J Fish Biol. 2009;75:290-4

37. Näslund J, Lindström E, Lai F, Jutfelt F. Behavioural responses to simulated bird attacks in marine three-spined sticklebacks after exposure to high CO2 levels (In press). Mar Freshwater Res 2015.

38. Thomas L. Retrospective power analysis. Conserv Biol. 1997;11:276-80.

39. Heuer RM, Grosell M. Physiological impacts of elevated carbon dioxide and ocean acidification on fish. Am J Physiol Regul Integr Comp Physiol. 2014:307:R1061-84

40. Ferrari MCO, McCormick MI, Munday PL, Meekan MG, Dixson DL, Lönnstedt $\mathrm{O}$, et al. Putting prey and predator into the $\mathrm{CO} 2$ equation - qualitative and quantitative effects of ocean acidification on predator-prey interactions. Ecol Lett. 2011;14:1143-8.
41. Leu E, Daase M, Schulz KG, Stuhr A, Riebesell U. Effect of ocean acidification on the fatty acid composition of a natural plankton community. Biogeosciences. 2013;10:1143-53.

42. Rossoll D, Bermúdez R, Hauss H, Schulz KG, Riebesell U, Sommer U, et al. Ocean acidification-induced food quality deterioration constrains trophic transfer. PLoS ONE. 2012:7:e34737-6.

43. Dwan K, Altman DG, Arnaiz JA, Bloom J, Chan A-W, Cronin E, et al. Systematic review of the empirical evidence of study publication bias and outcome reporting bias. PLoS ONE. 2008;3:e3081.

\section{Submit your next manuscript to BioMed Central and take full advantage of:}

- Convenient online submission

- Thorough peer review

- No space constraints or color figure charges

- Immediate publication on acceptance

- Inclusion in PubMed, CAS, Scopus and Google Scholar

- Research which is freely available for redistribution

Submit your manuscript at www.biomedcentral.com/submit 